\title{
The Participation Of Community And Stakeholders In Environmental Issue Management For Green Tourism In Thailand
}

Panisa Mechinda, Rajamangala University of Technology, Thailand Sirivan Serirat, Suan Dusit Rajabhat University, Thailand Nongluck Popichit, Suan Dusit Rajabhat University, Thailand

\begin{abstract}
The objective of this research is to study the environmental issues for green tourism development of Khao Yai Forest Complex by analyzing opportunities, threats, strengths, and weaknesses from the stakeholders' perspectives. According to weighted average score of strengths, weaknesses, opportunities, and threats, Khao Yai National Park is in the quadrant of SO (strengths and opportunities), indicating that they have strengths and opportunities and should therefore use aggressive strategy. Thap Lan National Park is in the quadrant of ST (strengths and threats), indicating that they have strengths and threats and should therefore use competitive strategy. In contrast, Pang Sida National Park, Ta Phraya National Park, and Dongyai Wildife Sanctuary are in the quadrant of WT (weaknesses and threats), indicating that they have weaknesses and threats and should therefore use defensive strategy.
\end{abstract}

Keywords: Environmental Issue Management; Green Tourism

\section{RESEARCH BACKGROUND AND SIGNIFICANCE}

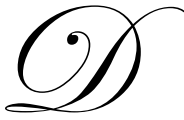

ong Phaya Yen - Khao Yai Forest Complex has been inscribed as Thailand's National World Heritage Site where there are plenty of natural resources, forest and wildlife, and a variety of biological life. It is an important and well-known destination for Thai and foreign tourists. It is comprised of four national parks - Khao Yai National Park, Thap Lan National Park, Pang Sida National Park, and Ta Phraya National Park - and Dongyai Wildlife Sanctuary (Department of National Park, Wildlife and Plant Convention (DNP) 2552.

Dong Phayayen-Khao Yai Forest Complex is a natural treasure for all biological lives, not only wild animals. If forests are destroyed, the ecological system will be affected and the wealth of surrounding communities will be destroyed (industry, agriculture, and tourism). Nowadays, Dong Phayayen-Khao Yai Forest Complex is under the supervision of the government alone. Furthermore, it faces various problems, such as hunting, cutting wood, forest invasion from people who lack environmental concerns and are ignorant of the values of this forest complex.

Researchers become aware of the importance of these problems which need to be resolved rapidly. In addition, it is essential to have full cooperation from multiple stakeholders (government, community and others) in developing green, sustainable tourism in the Dong Phayayen-Khao Yai Forest Complex for the next generation. 


\section{RESEARCH OBJECTIVE}

The objective of this research is to study the environmental issues for green tourism development of the Khao Yai Forest Complex by analyzing opportunities, threats, strength, and weaknesses from stakeholders' perspectives (tourists, communities, government officials, and others). So that urgent issues will be recognized, a solution to environmental problems will be developed and a search for cooperation from multiple stakeholders will be attained in solving the environmental problem at the world heritage of Dong Phayayen-Khao Yai Forest Complex.

\section{CONCEPTUAL FRAMEWORK}

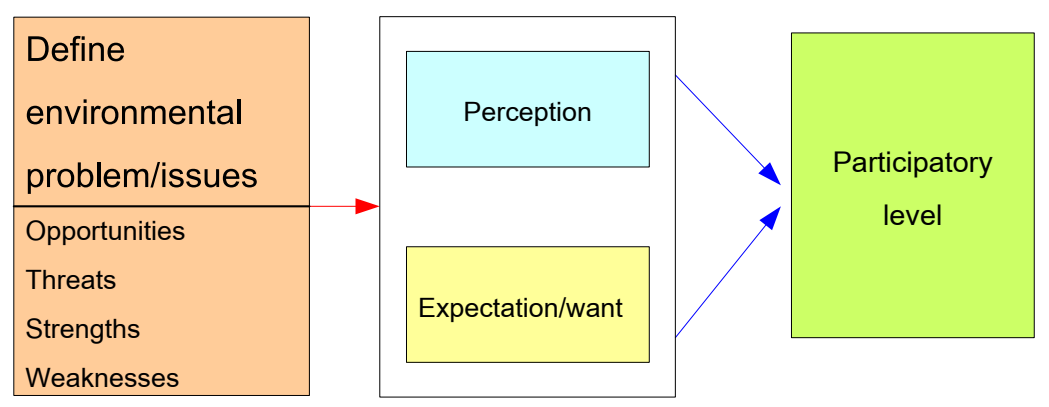

Figure 1: Conceptual Framework Literature Review of Stakeholders in Tourism Study

In this study, stakeholders are referred to as groups of people who relate directly to tourism. They gain positive benefits and are affected from negative problems/issues from tourism. They consist of tourist stakeholders, community stakeholders, government stakeholders, environment stakeholders, social activist stakeholders, and business stakeholders (Cottrell, Vaske \& Shen, 2005, p. 337)

\section{Sustainable Tourism}

Holden (2001) described the characteristics of sustainable tourism as follows: Firstly, the ecological system would not have a negative effect on the environment. Secondly, the economic system should contribute revenue to local community. Thirdly, the socio-cultural system should depend on an institutional perspective for management as a central facilitator to foster growth. Finally, institutional perspective should promote the community's participation. For instance, the government has to establish mutual activities to preserve the environment in the community. The government should emphasize on social responsibility, participation and involvement with tourism-related stakeholders. According to McKercher's sustainable tourism concepts (1993) and Hassan (2000), the focus is on the correct use of natural resources and maintaining those resources for future benefit. This will be done by developing high quality tourism products, by having the right policy in place, and by not destroying the environment.

\section{Green Environment}

The Tourism Authority of Thailand (2552) has set a green environmental policy as follows:

1. The culture of preserving the environment for sustainability and concrete effectiveness should be created using the three R's concept - reduce, reuse and recycle.

2. In terms of water preservation, water use in both community and business contexts should be managed and reduced. An efficient wastewater system should be established which should have no negative effect on the environment.

3. A green society should be established through the use of campaigns and social projects, such as "Forest Volunteer Project" and "Garbage Collection Campaign". 
4. Core values, comprised of visions, values, and milestones, should be cultivated and instilled in the organization.

\section{The Issue Management Process}

The process for managing issues is as follows: Firstly, environmental issues are identified by analyzing strengths, weaknesses, opportunities, and threats and the importance level from stakeholders' perspectives. Secondly, the issues are analyzed based on the following questions: (1) Who is affected from the issue/problem? (2) Who is interested in the issue/problem? (3) Who has influence on the issue/problem? Who has an opinion toward the issue/problem? (4) Who should deal with the issue/problem? (5) Who initiates the issue/problem? (6) Who currently participates in the issue/problem? (7) Who will participate in the future? Thirdly, the issues are prioritzed based on the following questions: (1) What are the issues to be done first? (2) What are the interesting - but not urgent issues? (3) What are the issues that may or may not happen? Fourthly, the method is created to solve or respond to the issue, and this response depends on an analysis of action. The organization can determine alternatives relevant to issues and then make a decision. Fifth, the methods are implemented to solve the problem. Finally, the methods are evaluated and monitored.

\section{RESEARCH METHODOLOGY}

The selected sample for this research comprises of community, tourist, government officers, and other stakeholders by using non-probability sampling as follows.

\section{Step 1}

Quota sampling is employed by proportionately assigning stakeholders of the National Park and Wildlife Sanctuary for five areas of 40 people each.

Step 2 samples.

Convenience sampling is used from each group in each area as identified in Step 1 for a total of 200

Table 1: Sample Size for National Park and Wildlife Sanctuary in Dong Phayayen-Khao Yai Forest Complex

\begin{tabular}{|l|c|c|c|c|c|}
\hline & $\begin{array}{c}\text { Khao Yai } \\
\text { National Park }\end{array}$ & $\begin{array}{c}\text { Thap Lan } \\
\text { National Park }\end{array}$ & $\begin{array}{c}\text { Pang Sida } \\
\text { National Park }\end{array}$ & $\begin{array}{c}\text { Ta Phraya } \\
\text { National Park }\end{array}$ & $\begin{array}{c}\text { Dongyai Wildlife } \\
\text { Sanctuary }\end{array}$ \\
\hline Community group & 10 & 10 & 10 & 10 & 10 \\
\hline Tourist group & 10 & 10 & 10 & 10 & 10 \\
\hline Government officer & 10 & 10 & 10 & 10 & 10 \\
\hline Other stakeholder & 10 & 10 & 10 & 10 & 10 \\
\hline Total & $\mathbf{4 0}$ & $\mathbf{4 0}$ & $\mathbf{4 0}$ & $\mathbf{4 0}$ & $\mathbf{4 0}$ \\
\hline
\end{tabular}

The methods of data collection are: 1) in-depth interviews and focus groups and 2) a questionnaire survey for evaluating strengths, weaknesses, opportunities, threats, and the importance of those factors that are related to green tourism.

\section{Qualitative Results}

The results of an interview with stakeholders in each destination of the Dong Phayayen-Khao Yai Forest Complex are described below. 


\section{Khao Yai National Park (Picture 1)}

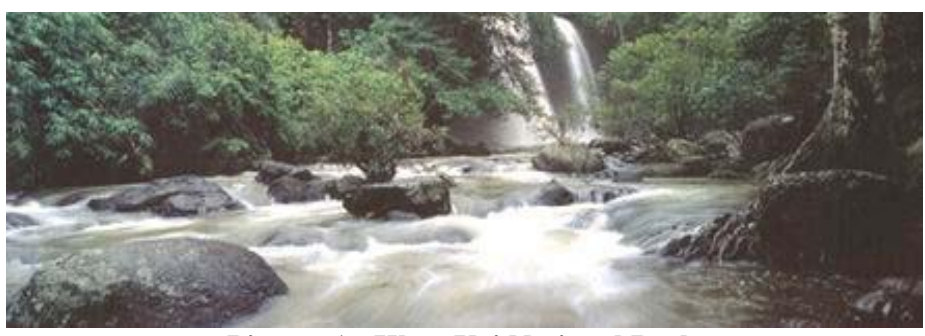

Picture 1: Khao Yai National Park

(http://www.dnp.go.th/parkreserve/asp/style1/default.asp?npid=9\&lg=2)

\section{Economic Issues/Problems}

In the past, local people grew corn and cassava, but now tourists are travelling within the area, bringing income to the community. For example, students in the community become young guides, people earn their income from selling products or being "Look-Harb" (Picture 2), and others become employees in resorts. However, some villagers who sell vegetables and fruits still need guidance from government officers regarding where to sell their products.

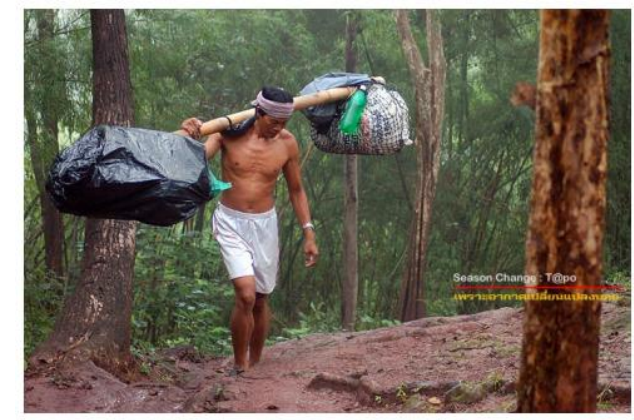

Picture 2: “Look-Harb” Villagers who Earn their Income by Carrying Things up the Hills for Tourists (www.monstersofts.multiply.com/journal/item/3)

\section{Socio-cultural Issues/Problems}

A media relation project is organized by providing knowledge to pupils and students in various educational institutions and these students become a medium of transferring knowledge to their parents and villagers. In doing so, cooperation to preserve the environment can be achieved. Furthermore, there is a project of giving knowledge to people in each community which helps them cooperate in preserving natural resources. There are many private residences around the national park rather than in it because of the fear of destroying the park's ecological system and national resources; however, tourists are allowed to stay overnight in camps.

\section{Environmental Issues/Problems}

Khao Yai is a world heritage and is very rich in beautiful scenery and ecological system. However, there are many problems, such as forest invasion. Some villagers, whose lands are connected with Khao Yai, have, for a long time, used this area to collect plants such as mushrooms, bamboo shoots, and fragrant woods (Picture 3). Furthermore, they sold the land, which legally did not belong to them, to private entrepreneurs to build resorts. Also, some villagers cut down trees and illegally collected rare plants to sell and they risked their lives of being arrested by government officials to sell prohibited items, such as eaglewood. 


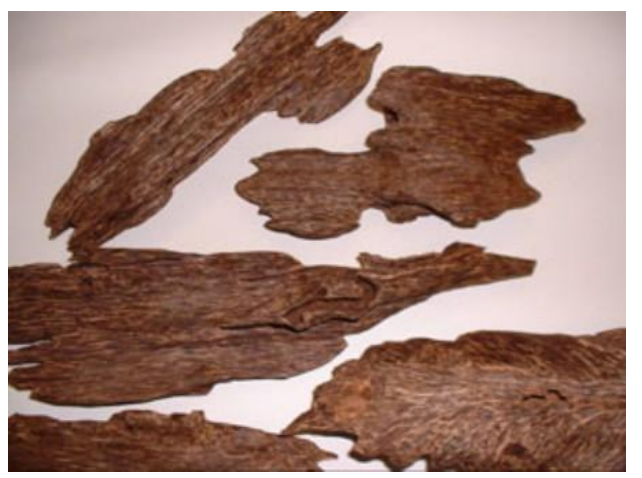

Picture 3: Krishna Fragrant Woods

(http://www.weloveshopping.com/shop/show article.php?shopid=190718\&qid=67094)

\section{Environmental Issues/Problems}

Migration to the area has caused hunting problems. People in the community hunt animals for food, but they may hunt elephant and gaur for money (Picture 4). Some wild animals in the Khao Yai National Park have lost their instinct, such as the pigtail monkey, and have been seen along the roads waiting for tourists to feed them (Picture 5). Although many resorts have a project for garbage disposition, there is still the problem of strong odors from garbage in the forest area.

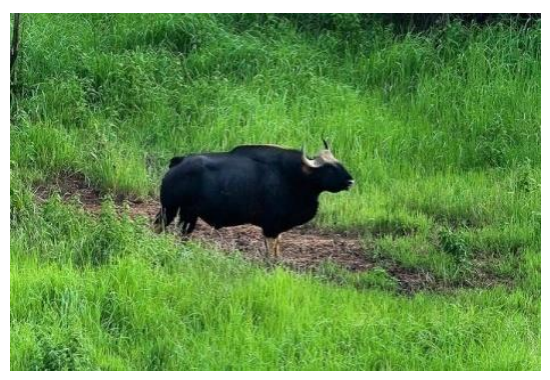

Picture 4: Gaur At Khao Yai (www.khaoyai-trekking.com/Animals.html)

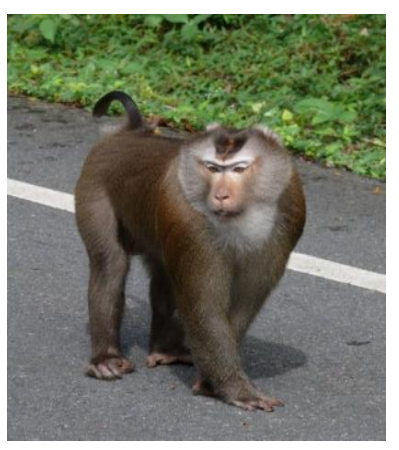

Picture 5: Pigtail Monkey Along The Road Waiting For Tourists To Feed Them

\section{Managerial Issues/Problems}

National park officers should be trained so that they can apply knowledge in preserving the environment. The government does not recognize the importance of being a ranger, so he is paid a low salary and does not receive welfare. Because they are so many tourists, the officers cannot provide sufficient destination and route information for a nature study. Problems arise from camping and the lack of sufficient restrooms. In some areas, people settled before Khao Yai became a world heritage, so the government cannot push them out; but the government should restrict construction of resorts in the nearby area because too many resorts can negatively affect the overall scenery and environment. 


\section{Thap Lan National Park (Picture 6)}

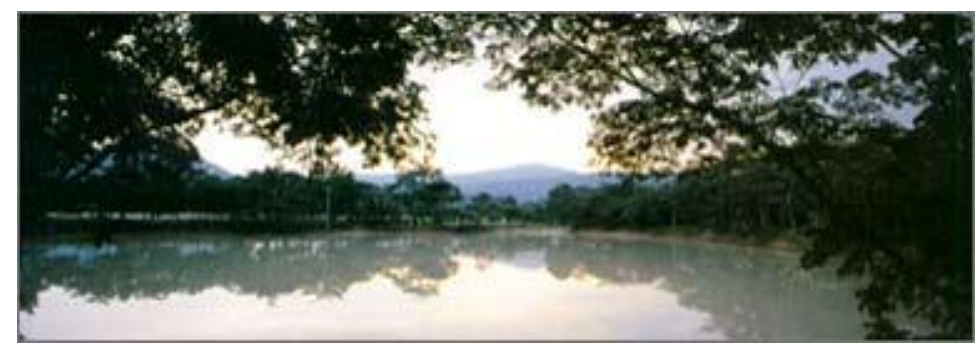

Picture 6: Thap Lan National Park

(http://www.dnp.go.th/parkreserve/asp/style1/default.asp?npid=97\&lg=2)

\section{Economic Issues/Problems}

Thap Lan National Park is very famous and receives much attention from tourists. As a result, there is much development in terms of accommodations, roads, and infrastructure. The park receives a high revenue - as much as 10 million Baht - from tourism; however, whether tourism in this area is profitable or not depends on garbage disposal, which requires planning and budgeting.

\section{Socio-cultural Issues/Problems}

Being a World Heritage destination is an advantage, but a drawback is that government officials cannot educate the communities of appropriate behavior in order to preserve World Heritage destination status. In addition, some officials do not have sufficient equipment to do their jobs effectively.

\section{Environmental Issues/Problems}

This forest complex is $70 \%$ plentiful as it is the origin of the Mool and Bang Pakong rivers. It is a big reservoir which can absorb water by $50 \%$. However, the community needs to manage it well because wild animals, such as elephants and gaur, come down from the forest for water in the summer. Because water and food may not enough for them, government officers try to grow plants for them and create artificial food (Artificial Pong as shown in Picture 7).

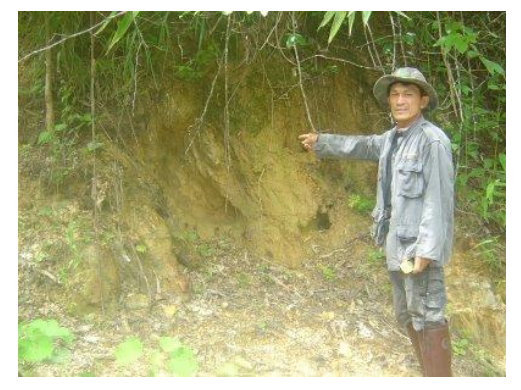

Picture 7: Artificial Pong, a Soil Mixed with Calcium for Elephants (www.elephantreintroduction.blogspot.com)

The community near this forest complex experiences a problem of water ruined by chemical substance (especially in the village that grows cane, cassava, and corn), so the people cannot drink or use it. Local residents regularly collect something from the forest, such as mushrooms, Pak Whan (Melientha Suavis Pierre - Picture 8), Pakria (Picture 9), Red ant's eggs (Picture 10), etc. Also, the community experiences drought in the summer and flooding in the rainy season due to deforestation. 


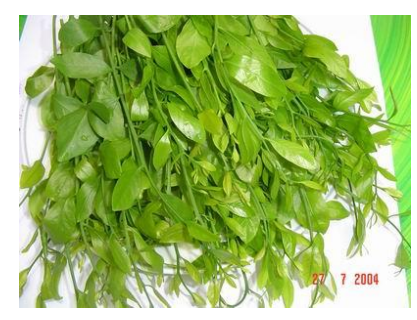

Picture 8: "PAK WHAN" (www.oknation.net)

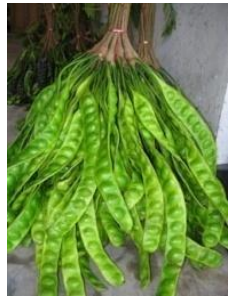

Picture 9: Pakria (www.mblog.manager.co.th)

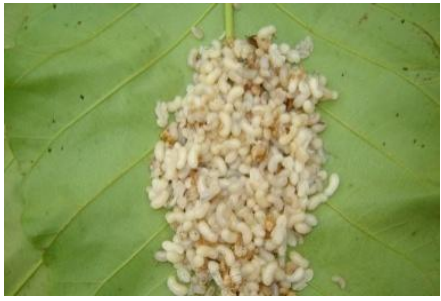

Picture 10: Red Ants Eggs (www.epofclinic.com)

\section{Managerial Issues/Problems}

A problem exists of invasion by the villagers into the reserved forest area. Villagers claimed that the lands belonged to them to use for cultivation. However, the lands produced nothing, thus they were in debt. They finally had to sell the lands which caused ownership transferring problems.

The public highway department recently studied road construction around the forest complex to build above-ground and underground passageways for cars and wild animals. Moreover, there is a shortage of officers due to turnover problems because they have low fringe benefits and no job security.

\section{Pang Sida National Park (Picture 11)}

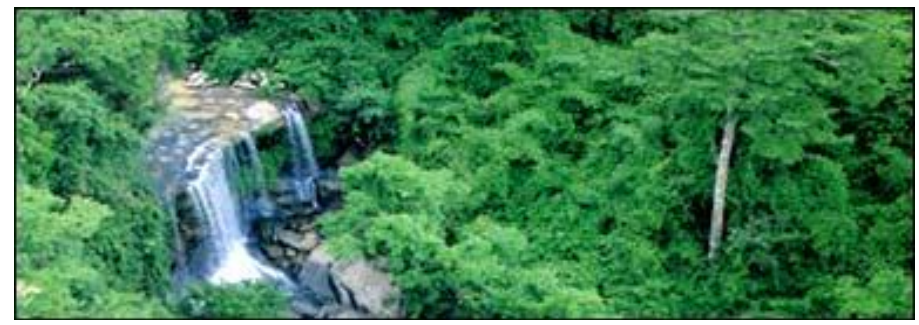

Picture 11: Pang Sida National Park

(http://www.dnp.go.th/parkreserve/asp/style1/default.asp?npid=101\&lg=2)

\section{Economic Issues/Problems}

Villagers near the national park earn more money because tourists who stay overnight or camp buy products before entering the park.

Government officers have talked with community leaders about tourism cooperation, but there is a limited operating budget. There is growth in ecological tourism in this area, so the Tourism Authority of Thailand has recently organized and promoted special events, such as Butterfly Festivals (Picture 12) to improve the economy in this area. 


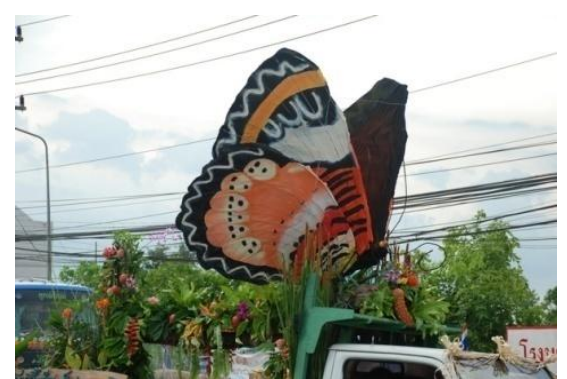

Picture 12: Butterfly Festivals held at Pang Sida National Park (http://travel.kapook.com/photo/travel 3925.html)

\section{Socio-cultural Issues/Problems}

Some villagers hunt wild animals, which is illegal, but because the park area is vast and there is not a sufficient number of officers, they are not arrested. However, the problem has lessened because villagers are being educated and trained. There is currently an outside organization - Finland Foundation - that is providing training for a tiger survey project, so cameras have been installed for tourists to watch the tigers.

\section{Environmental Issues/Problems}

This forest complex has many tigers and butterflies, which is an indicator of natural richness. As a result, the officers have made artificial saline soil by adding some useful minerals to the soil and they have created sources of water for the wild animals. Because of thorough investigations of the officers, situations of collecting forest products to sell, hunting wild animals, and invading the forest have decreased.

Ecological tourism does not negatively affect the environment in the park if there is a suitable level of supervision, such as for taking a trip in the forest or birds watching. In doing such activities, tourists should be informed not to make loud noises because it may disturb the animals and force them to migrate out of the forest area.

\section{Managerial Issues/Problems}

Because this area is under the Agricultural Land Reform Office, if private sectors want to erect resorts, they have to build them outside the park areas, or they can do home stay instead. Regarding the invasion problem from villagers, government officials are solving this problem by determining an area for the park and an area for the community.

Related sectors have to cooperate in keeping the variety and natural richness of this forest complex according to the condition of World Heritage of UNESCO. Currently, the officers have no data regarding the forest complex area and wild animals, but they are now assigned to survey and collect qualitative data, such as animal footprints and interesting breeds of plants, and record them on a map to indicate the area for preservation planning in the future. 


\section{Ta Phraya National Park (Picture 13)}

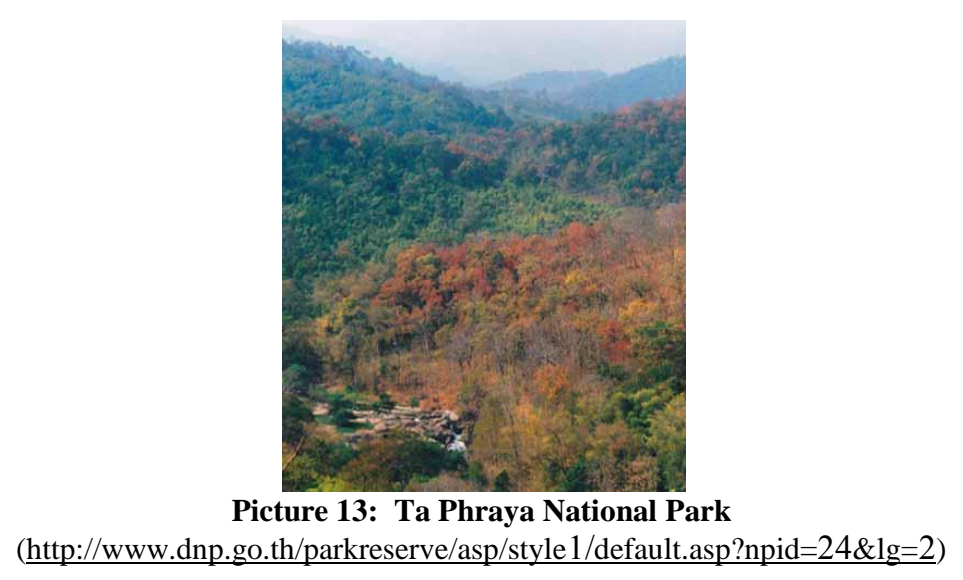

Economic Issues/Problems

The income from tourism in this national park has decreased due to economic problems. Moreover, this national park is far from the main tourism attraction and is inferior to Khao Yai in terms of tourism facilities.

Socio-cultural Issues/Problems

The problem of the Ta Phraya National Park is caused by tourists. There are two types of tourists - those who are ecological and those who are not. The latter group made a lot of noise, which scared the gaur out of the forest. The officers have now warned them of their behavior and educated the community to cooperate with them in improving the national park. This has been effective, thus reducing the problem of invasion, deforestation, and animal hunting, as well as building a good relationship between officers and the community.

The campaign in building environmental mindedness is more effective with the young than with the villagers who only concern themselves for their own benefit. The problem arises from their own poverty, the land to grow their plants, and the ability to have extra jobs. Illegal situations by villagers decrease during rice farming but increase when they have nothing to do for a living. As a consequence, the government should help villagers find extra jobs during the period of no rice farming.

\section{Environmental Issues/Problems}

The natural richness of this forest is rather high. Currently, we can control villagers by teaching them to be concerned about the forest, but deforestation is caused by local residents and officers cannot completely watch them. As a result of cameras being installed by US students, many kinds of wild animals can be seen, such as leopard cat, pig-tailed Macaque, and serow, as well as tiger footprints. In terms of hunting, some people hunt squirrels and chipmunks.

This forest is the source of water, so the government is building more dams and reservoirs for wild animals. The problem of collecting forest products illegally has decreased because of government officers' active works.

\section{Management Issues/Problems}

In the past, some villagers sold their land to landlords and then invaded the forest again because there were not enough officers. However, nowadays, there are many representatives from the government, such as officers from the Royal Forest Department, border patrol police, and soldiers, consequently making forest invasion more difficult. 
In order for ecological tourism to be successful, the park officers need participation from the community. By being tourist guides, the community can earn revenue without illegally collecting forest items or hunting.

\section{Dongyai Wildlife Sanctuary (Picture 14)}

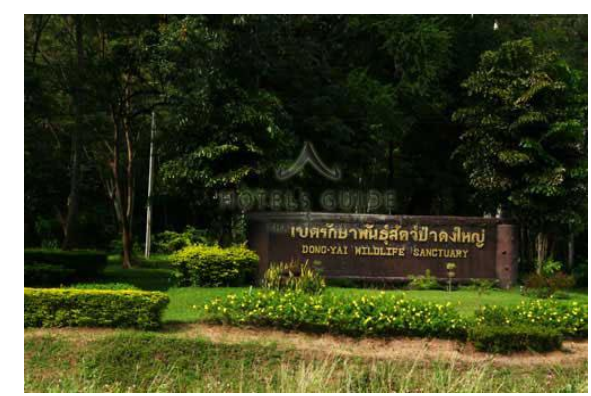

Picture 14: Dong Yai Wildlife Sanctuary

(www.hotelsguidethailand.com/trav...e\%3D2257)

\section{Economic Issues/Problems}

Income from tourism is not stable because there is no regulation in collecting fees for those who want to enter the park. Tourism creates less income for the nearby community because the government did not open this park for tourists.

\section{Socio cultural Issues/Problems}

Regulations exist for tourists and villagers who break the rules. Tourists create little problems, such as throwing away garbage; but villagers create problems, such as deforestation, that are subject to punishment. They are warned when they collect forest products such as orchids and cogon grass (Picture 15).

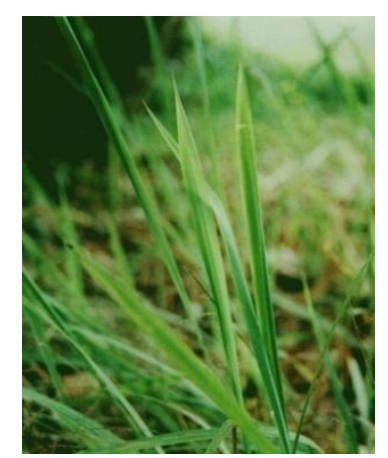

Picture 15: Cogon Grass being Illegally Collected by the Villagers (http://www.uru.ac.th)

There are only a few officers, so the government needs cooperation from communities to preserve the environment and to support it in terms of budget and equipment from other governmental agencies. However, it is difficult to get cooperation from communities because the officers don't know their real motives. Only some communities take part in forest substitution and environment restoration, and in doing so, they can promote their community to be a tourist attraction. Some outside agencies help with planting the forest or building dams, but not on a continuous basis. 


\section{Environmental Issues/Problems}

The natural richness of this forest is about $80 \%$. As a result, the animals will not leave the forest and invade into the community for food. There is still a problem of deforestation. There are variety of plants and wellknown wild animals, such as elephant and gaur. Another problem comes from the villagers, who use chemical substances in farming, which flows into the water making it toxic for the animals to drink. There is currently a project of building reservoirs in the forest to prevent animals from leaving.

Villagers always come into the forest seeking products such as orchids, rattans (Picture 16), and cogon grass for selling to tourists. However, they cooperate with the government in forest planting because they know that their lives are dependent on the life of the forest. Furthermore, there is also a project to bring Dracaena to the Dongyai Forest (Picture 17), which was persuaded by villagers to buy Dracaena that students grow for a low price. Another problem comes from villagers who do not have sufficient income, so they invade the forest for agriculture (growing Eucalyptus, cassava, and tapioca).

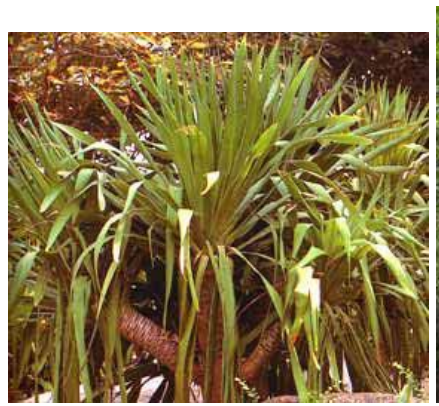

Picture 16: "Rattans" (www.oknation.net)

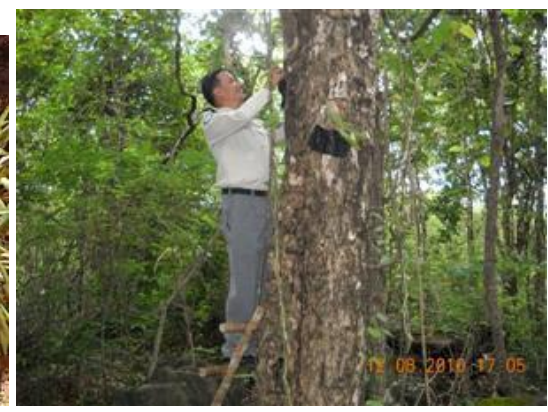

Picture 17: Special Project Bringing Dracaena to Dongyai Forest (www.oknation.net)

Managerial Issues/Problems

There are plans to manage the conflict of land ownership. The short-term plan is to move people who invade the forest out of forest area and to provide them with land for their own cultivation.

\section{Quantitative Results}

The results in this section are derived from a questionnaire that was completed by all stakeholders from each tourism destination of the Don Phayayen-khao Yai Forest Complex. First, the mean for each SWOT item is calculated from 40 respondents. Then the importance score for each SWOT item is calculated and its proportion is determined. The mean for each SWOT item is then multiplied by its proportion and the weighted means are accumulated. Finally, the final score is assigned on the TOWS matrix which consists of four levels: $1.00-2.00$ (high weaknesses, high threats), $2.01-3.00$ (weaknesses/threats), $3.10-4.00$ (strengths/opportunities), and $4.01-$ 5.00 (high strengths/high opportunities).

Table 2: Weighted Score of SWOT Evaluation for Each Destination

\begin{tabular}{|l|c|l|c|c|}
\hline $\begin{array}{c}\text { Dong Phayayen-Khao Yai Forest } \\
\text { Complex Destination }\end{array}$ & $\begin{array}{c}\text { Weighted Score of Strengths/Weaknesses } \\
\text { Evaluation }\end{array}$ & \multicolumn{2}{c|}{$\begin{array}{c}\text { Weighted Score of } \\
\text { Opportunities/Threats Evaluation }\end{array}$} \\
\hline Khao Yai National Park & 3.31 & Strength & 3.26 & Opportunity \\
\hline Thap Lan National Park & 3.02 & Strength & 2.87 & Threat \\
\hline Pang Sida National Park & 2.79 & Weakness & 2.58 & Threat \\
\hline Ta Phraya National Park & 2.68 & Weakness & 2.85 & Threat \\
\hline Dongyai Wildlife Sanctuary & 2.64 & Weakness & 2.46 & Threat \\
\hline
\end{tabular}




\section{TOWS}

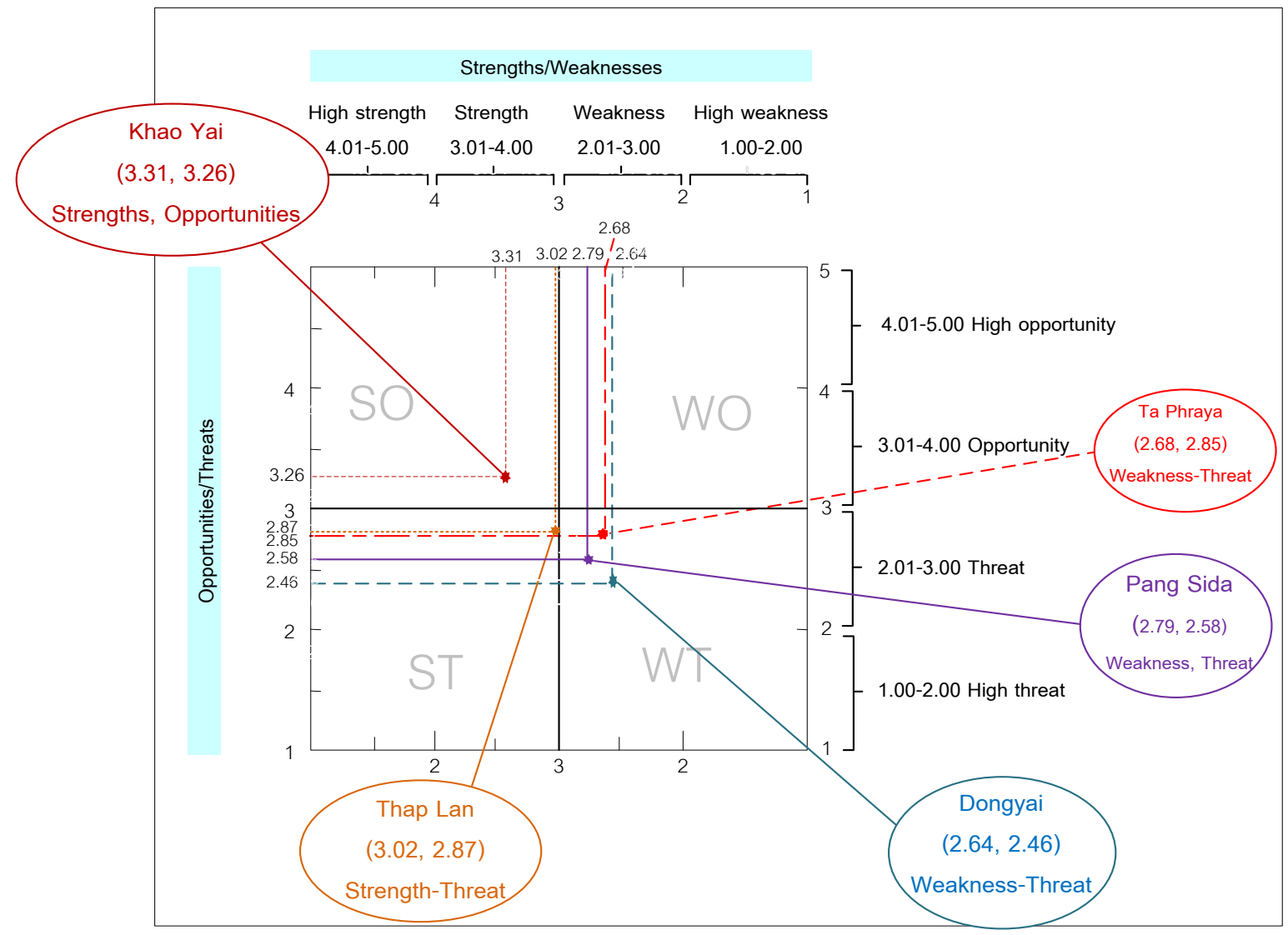

Figure 2: Position of TOWS Matrix for Tourism Destination in Don Phayayen-Khao Yai Forest Complex

According to Table 2 and Tows Matrix in Figure 1, Khao Yai National Park is in the SO position (Strengths and Opportunity). Thap Lan National Park has scored in the ST position (Strengths and Threat), Pang Sida National Park has scored in the WT position (Weaknesses and Threat), and Dongyai Wildlife Sanctuary has scored in the WT position (Weaknesses and Threat). Therefore, Khao Yai National Park should use an aggressive strategy by using strengths for building advantages from opportunities they have. Thap Lan National Park should use a competitive strategy by using strengths to get rid of threats. Pang Sida National Park, Ta Pharaya National Park, and Dongyai Wildlife Sanctuary should use a defensive strategy by eliminating internal issues/problems that are weaknesses and minimizing external issues/problems that are threats (Weihrich \& Koontz, 1993, p. 175).

\section{MANAGERIAL IMPLICATIONS}

Khao Yai National Park should use its strengths and opportunities to create advantages as follows:

1. Community area surrounding the park areas has to be developed to become an agricultural tourism destination. As a result, income for the community can be generated and tourists will be more attracted to Khao Yai National Park. Moreover, there are many communities that still need advice from officers about where to sell goods.

2. Ecological tourism activities must be emphasized through community participation, such as establishing a source of agricultural learning in communities and training the tourist guides to provide knowledge about the route. This can reduce the problem of invading natural resources of communities and the problem of garbage incurred from tourism. 

as follows:

Thap Lan National Park should use a competitive strategy and use its strengths for eliminating the threats

1. The image of being a national World Heritage tourism destination should be promoted. The value of being a palm forest should be recognized and communicated to all stakeholders in order that all of them know how to behave to maintain this forest.

2. A network for forest/animal preservation should be created. Moreover, they should solve the problem of a lack of officers in the future by providing them appropriate job security.

Pang Sida National Park should minimize threats and weaknesses as follows:

1. Ecological tourism should be stressed because the forest is naturally rich and has many waterfalls.

2. The forest should be promoted as a Natural World Heritage tourism destination.

3. A learning center regarding genetics of butterflies, together with butterfly festivals, should be created. Furthermore, vocational training should be provided for the community so that they have their own jobs to generate income. This, in turn, will reduce the problem of forest invasion and animal hunting.

Ta Phraya National Park should eliminate internal problems (weaknesses) and minimize threats as follows:

1. First, various activities should be arranged for tourists of all ages. This national park needs marketing support from the Tourism Authority of Thailand to promote the park.

2. The government should provide correct information to tourists about communist groups and discovery of bombs in this area since these rumors scare tourists away.

Dongyai Wildlife Sanctuary should eliminate its weakness and threats as follows:

1. There is an insufficient amount of accommodations in this park because the government's policy is to reserve the forest. The officers should allow ecological tourists (those who really want to study nature) to stay in the park.

2. The government should solve the problem of forest invasion by providing jobs to villagers. If they have jobs and earn income, they will not destroy the forest.

\section{LIMITATION AND SUGGESTION FOR FUTURE RESEARCH}

Future research should be conducted from tourists' perspectives to determine the competitiveness as well as to create a marketing plan for destination branding and sustainable tourism.

\section{AUTHOR INFORMATION}

Associate Professor Sirivan Serirat currently works for Suan Dusit Rajabhat University. Her research interests are in tourism, sustainable tourism and brand equity. E-mail: sirivanonline@ gmail.com. Corresponding author.

Assistant Professor Dr. Panisa Mechinda is a full-time lecturer at Rajamangala University of Technology Thanyaburi. Her research interests are in tourism, brand equity and service marketing. E-mail: panisatungtoh@hotmail.com

Nongluck Popichit is a full-time lecturer at Suan Dusit Rajabhat University. Her research interests are in management and tourism. E-mail: npopichit@gmail.com

\section{REFERENCES}

1. Cottrell, S., Vaske, J. \& Shen, F. (2005). Predictors of Sustainable Tourism: Resident Perceptions of Tourism in Holland and China. Proceedings of the 2005 Northeatern Recreation Research Symposium. New York: USDA Forest Service, Norteastern Research Station. pp. 337-344. 
2. Department of National Parks, Wildlife and Plant Conservation. (2003). News for Ecotourist. [Online]. Available: http://www.dnp.go.th/parkreserve/ asp/style1/default.asp?npid=9\&lg=2

3. _ (2008). News of National Parks. [Online]. Available: http://park.dnp.go.th/visitor/shownews.php?newsid=680

$4 . \quad$. (2010). Ta Phraya National Park. [Online]. Available: http://www.dnp.go.th/parkreserve/asp/tyle1/default.asp? pid=24\&lg=2

5. . (2011). Thap Lan National Park. [Online]. Available:

http://www.dnp.go.th/parkreserve/asp/style1/default.asp?npid =9\&lg=2

6. Elephant Reintroduction Foundation. (2011). Management of Elephants in Thailand. [Online]. Available: http://www.elephantre-introduction.blogspot.com/ [2011, August 30, Tuesday]

7. Hassan, S. (2000). Determinants of Market Competitiveness in an Environmentally Sustainable Tourism Industry. Travel Research, 38 (3), pp. 239-245.

8. Holden, A. (2001). Environment and Tourism, New York: Routledge.

9. Isara Sukkum. (2010). Discover the True Nature of Thailand. [Online]. Available : http://www.khaoyaitrekking.com/Animals.html

10. McKercher, R. (1993). The Unrecognized Threat: Con Tourism Survive Sustainability. Tourism Management, 14 (2), pp. 131-136.

11. OkNation.net. [Online]. Available : http://www.oknation.net/blog/.com

12. Rakpangsida Association. (2010). Butterfly Festival at Pang Sida National Park $6^{\text {th }}$ 2010. [Online]. Available : http://travel.kapook.com/photo/travel 3925.html

13. Sirimanas Eakwasin. (2004). Krisana and Herb. [Online]. Available: http://www.weloveshopping.com/shop/show_article.php?shopid=190718\&qid=67094)

14. THiNKNET Co., Ltd. (2010). Booking toward Hotel and Resort in Thailand. [Online]. Available: http://www.hotelsguidethailand.com/

15. Tourism Authority of Thailand. (2009). [Online]. Available: http://thai.tourismthailand.org/home/

16. Trips Talui Slug at Phukradung. [Online]. Available: www.monstersofts.multiply.com/ journal/item/3

17. Uttaradit Rajabhat University. (2000). Cogon grass (Yaa khaa). [Online]. Available: http://www.uru.ac.th/

18. Weihrich, H. \& Koontz, K. (1993). Management: A Global Perspective. (10th ed). New York: McGrawHill. 